\title{
Hesitant Fuzzy Linguistic Decision Approach for Stroller Selection
}

\author{
Billur Ecer* \\ Ankara Yıldırım Beyazıt University, Department of Industrial Engineering, Ankara, Turkey
}

(ORCID: 0000-0001-9692-1450)

\begin{abstract}
Having a baby brings new changes and challenges in parents' life. There is a list of things which are required in order to provide a comfortable life for the baby. Since most of the people have limited economic resources, determination of the things to be bought becomes an important decision for parents. Moreover, the number of alternatives for the items in shopping list (bed, clothes, feeding equipment, stroller, etc.) is very much. Therefore, making a choice among alternative items is necessary. For each item, different alternatives have several advantages over another in views of different aspects. Consideration of several aspects of items would lead to good decisions, and parents must evaluate things in this way. It is aimed in this research to develop an analytic decision-making approach for stroller selection decision of parents. Hesitant fuzzy linguistic terms set (HFLTS) approach was presented in order to model the uncertain situations that the decision makers feel hesitant over various values of a linguistic variable. By using this pattern, elicitation of linguistic information is improved and thoughts of decision makers are represented better in decision models. Under the consideration of hesitant feelings of parents, HFLTS based group decision making approach is utilized to determine the optimum stroller. Apracticeof the presented model is presented to indicate its applicability and the presented decision approach seems useful for stroller selection.
\end{abstract}

Keywords: Hesitant fuzzy sets, Multi-criteria decision making, Stroller selection, Group decision making, Hesitant fuzzy linguistic terms set.

\section{Bebek Arabası Seçimi İçin Tereddütlü Bulanık Dilsel Karar Yaklaşımı}

\begin{abstract}
Özet
Bebek sahibi olmak ebeveynlerin yaşamına yeni değișimler ve zorlukları da beraberinde getirir. Bebeğe rahat bir yaşam sunabilmek için gereken pek çok şey vardır. Çoğu insanın sınırlı ekonomik kaynakları olmasından ötürü, satın alınacak nesnelerin belirlenmesi ebeveynler için önemli bir karar haline gelmektedir. Ayrıca, alınması gereken her bir nesne (yatak, kıyafet, besleme ekipmanları, bebek arabası, vb.) için çok sayıda seçenek vardır. Bu nedenle, seçenekler arasında bir seçim yapmak gereklidir. Farklı seçeneklerin diğerleri üzerinde farklı yönlerden üstünlükleri söz konusudur. Farklı yönleri dikkate almak iyi bir karar vermeyi sağlayacaktır, ebeveynlerin de bu yönde hareket etmelidir. Bu çalışmada, ebeveynlerin bebek arabası seçimi kararı için analitik bir karar modeli geliştirmek amaçlanmıştır. Tereddütlü bulanık dilsel terimler kümesi (Hesitant Fuzzy Linguistic Terms Set = HFLTS) yaklaşımı, karar vericilerin dilsel bir değişkenin çeşitli değerleri arasında kararsız kaldığı kesin olmayan durumları modellemek için geliştirilmiştir. Bu yaklaşım kullanılarak dilsel bilginin çıkarımı iyileştirilmekte ve karar vericilerin düşünceleri karar modellerinde daha iyi temsil edilebilmektedir. Ebeveynlerin kararsız hislere sahip olacağı düşüncesi altında HFLTS temelli grup karar verme yaklaşımı en iyi bebek arabasını bulmak için kullanılmıştır. Yaklaşımın uygulanabilirliğini göstermek üzere bir uygulama çalışması sunulmuş ve önerilen modelin bebek arabası seçiminde kullanışlı olduğu görülmüştür.
\end{abstract}

Anahtar kelimeler: Tereddütlü bulanık kümeler, Çok kriterli karar verme, Bebek arabası seçimi, Grup karar verme, Tereddütlü bulanık dilsel terimler kümesi.

*Corresponding author: becer@ybu.edu.tr

Received: 01.07.2021, Accepted: 25.08.2021 


\section{Introduction}

Decision making is a common activity of daily lives of people. Some examples of everyday life decisions are choosing a variety of products for shopping, determination a table to sit in a restaurant, or setting a driving route from start to destination. There must be a selection process between at least two options in order to talk about making a decision. It is not possible to talk about a decision if the decision maker has only one alternative. Also, making a decision by considering one criterion is simple. The option close to the best value is chosen. However, decision-making in general requires considering several criteria at the same time.

In such cases, the decision-making problem turns into a more complex structure. Because in these situations the decision criteria are often contradictory. For example, the decision to buy a car requires considering several criteria simultaneously. Comfort, fuel consumption, power, safety, selling price, etc. can be considered as several aspects of this decision. Cars providing more comfort are generally expensive, on the other hand cars with less selling prices generally generate less power. So, making a decision that satisfy all aspects of the decision is mostly impracticable. Hence, decision maker must make a good decision by considering all criteria.

Decision problems with a limited number of criteria and a limited number of alternatives to evaluate are described as multi-criteria decision making (MCDM) problems. Besides they have similar steps, there are too many different MCDM methods proposed and applied on several decision problems by researchers so far. Some of the most common MCDM techniques can be listed as Analytic Hierarchy Process (AHP), Analytic Network Process (ANP) and Technique of Order Preference by Similarity to Ideal Solution (TOPSIS). MCDM techniques can be easily used on any decision problems to obtain solution, without considering they have qualitative or quantitative criteria.

In some cases, decision elements can be defined using linguistic variables. Usage of linguistic variables may cause uncertainty about decision elements, because different experts can define dissimilar values by using identical linguistic terms. For example, height of a man can be indicated by using "short", "medium" and "tall" words. One person can describe a man with $180 \mathrm{~cm}$ height with "tall" word and another person can define a man with $190 \mathrm{~cm}$ height as "tall". Fuzzy set theory is used to evaluate such uncertainties caused by linguistic expressions. Zadeh [1] introduced fuzzy set theory into literature and Bellmann and Zadeh [2] integrated fuzzy logic into decision-making problems.

Several weaknesses and shortages of ordinal fuzzy set (FS) theory of Zadeh has been improved by researchers based on the methodological progresses. Most common extensions of FS theory are typeII FSs [3], intuitionistic FSs [4], neutrosophic FSs [5] and hesitant FSs [6].

Hesitant FSs were introduced into the literature to define hesitant feelings several values of an element that people face during the evaluation process. The ability to model hesitant emotions using hesitant fuzzy sets has caught the attention of researchers to integrate the concept into decision-making practices. Rodriguez et al. [7] developed an approach named hesitant fuzzy linguistic term sets (HFLTS). HFLTS concept helps decision makers to express their hesitant feelings using a context-free grammar.

HFLTS provides the opportunity to use compound terms defined by context-independent grammar, where fuzzy linguistic approach restricts experts to express their thoughts in a single term. The opportunity to use multiple linguistic terms for expressions is the main advantage over other fuzzy approaches.

Decision making models based on HFLTS have been developed to find solutions to a wide variety of problem areas, so far. Yavuz et al. [8] developed a group decision making (GDM) based of HFLTS to evaluate alternative fuel buses. A likelihood-based TODIM approach based on multi-hesitant fuzzy linguistic (HFL) information was used to assess third party logistics service providers [9]. Prioritization of patients in a hospital of China was made by using a HFL Projection-Based MABAC approach [10]. Feasibility of application of HFLTS based TOPSIS and VIKOR methods on healthcare waste disposal management evaluation was illustrated on an example [11]. Assessment of alternative hotel locations was evaluated by using a HFLTS based ELECTRE-III method [12]. Extension of ORESTE method with HFL elements was presented as a way to obtain solution of supplier selection problem [13]. Hesitant 2-tuple linguistic term sets based QUALIFLEX method was used to evaluate alternative robots in manufacturing systems [14]. Social sustainability assessment of small hydro power plants was made using ANP and HFLTS based PROMETHEE method [15]. Risks of urban rooftop distributed photovoltaics in energy performance contracting (EPC) projects were evaluated by using the 
HFLTS based DEMATEL approach [16]. Hesitant fuzzy linguistic extension of BWM was proposed by Liao et al. [17] and tested on a case study on hospital performance evaluation. Websites of 70 Industrial Engineering departments in Turkey was evaluated in views of search engine optimization criteria by using a HFLTS based approach to determine criteria weights and a TOPSIS application to evaluate websites [18]. Weights of selection criteria of the eco-friendly cities were determined by using a HFLTS based approach and 81 cities in Turkey were evaluated by using ARAS method [19]. Readers may refer to review studies conducted by Hai et al. [20] and Liao et al. [21] for developments and applications of hesitant fuzzy linguistic decision-making applications.

The GDM methodology based on HFLTS of Yavuz et al. [8] was applied in this study on stroller selection decision of parents for a new-born baby. Parents may hesitate to express their opinion on selection criteria and alternative features. The HFLTS based group decision making approach provides the ability to evaluate decision elements by pairwise comparisons and to express hesitant feeling of decision makers. In this way, it becomes easier to obtain solutions from many alternatives by considering conflicting criteria, without the need for numerical data for criteria and alternatives.

The remainder of this paper is as follows: A summary of HFLTS based decision making applications was presented in the second part. Third part consists of a short description of methodology. Application of stroller selection with the method was presented in the fourth part. Finally, conclusion of the study by providing comments and suggestions for further research was given in the fifth part.

\section{Material and Methods}

Decision making is an ordinary activity of everyday life. A simple definition of decision making can be made as choosing an alternative from a set of possible options. In most cases, making a decision involves considering several criteria simultaneously. In such conditions, the decision problem gets a more complicated structure; because the existence of several criteria makes the decision problem contradictory. Some of the alternatives may be better in views of some criteria, while others may be better for other criteria. At this point, making a decision becomes more difficult. Decision problems with a limited number of alternatives and many criteria are named as multiple criteria decision making problems. There are several methods have been proposed in the literature to model and solve multiple criteria decision making problems.

There are three groups of decision making problems related to the structure of problem data:

i. decision making under certainty,

ii. decision making under risk,

iii. decision making under uncertainty.

The first group refers to decision problem having certain data. The second group defines the situations that the problem data is expressed by some probability distributions. The group of decision making by considering uncertainty consists the decision problems with uncertain data which cannot be expressed by statistical distributions. Fuzzy logic is commonly used for decision making under uncertainty, because fuzzy logic is appropriate for dealing with uncertain or linguistic terms having no past data or probability distributions.

In this study, the GDM approach based on HFLTS proposed by Yavuz et al. [8] was used for selection of the best stroller for a new-born baby. HFLTS is used in this study, because this approach gives the opportunity to model hesitant feelings of decision makers in rating of criteria and alternatives. The algorithm steps are as follows:

Step 1: Determine the problem goal, criteria and alternatives.

Step 2: Determine the linguistic terms and context - free grammar.

Step 3: Collect users' opinions for criteria and decision options.

Step 4: Convert users' opinions into HFLTS.

Step 5: Obtain the collective preferences.

Step 6: Build the vector of intervals for collective preferences.

Step 7: Obtain the priority values after normalization of intervals.

Step 8: Select the best stroller 
These steps of the algorithm were given in detail in the next section of the study.

\section{Results and Discussion}

This part presents the application steps in detail for stroller selection. Parents of the baby (mother and father) and grandmother were considered as the user group of the stroller. Thoughts and feelings of 3 users were collected for evaluation of criteria and alternatives. Mother is expected to be the user for $50 \%$ of time, while father is expected to use the stroller $30 \%$ of time and the rest $20 \%$ is considered for grandmother. The usage rates given here were used for opinion aggregation weights. Details for steps of the decision approach are explained as follows:

Step 1: Determine the goal, criteria and alternatives: The goal of the problem is determination of the best stroller among four alternatives (A1 - A4). Weight (C1), ease of use (C2), dimensions (C3), price (C4) and comfort of baby (C5) were taken into account as evaluation criteria. Decision hierarchy of stroller selection was presented in Figure 1.

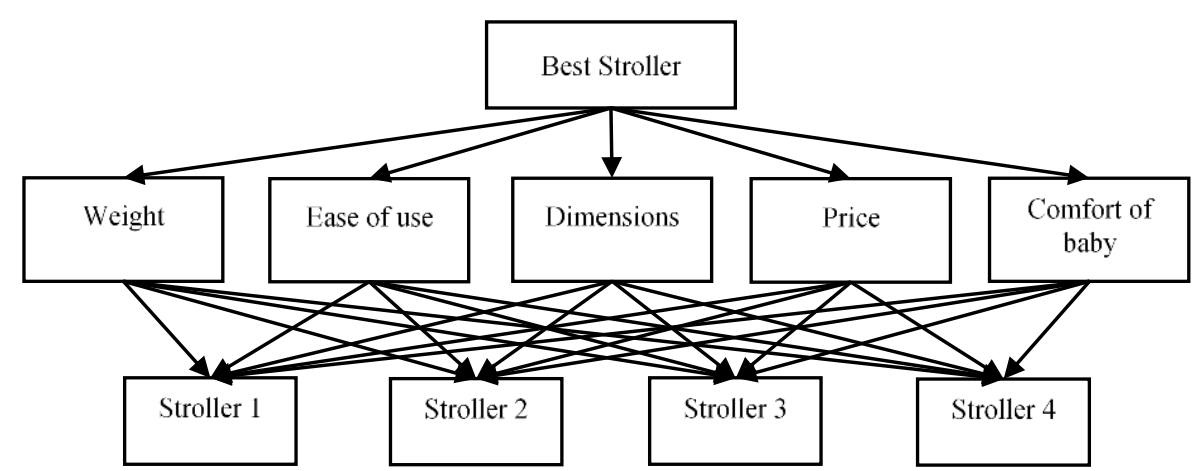

Figure 1. Structure of the decision problem

Step 2: Determine the linguistic terms and context - free grammar: Linguistic terms for importance degrees used in the study are given in Table 1. Linguistic terms are connected to the others by using an appropriate relation term from the set of "at most", "at least", "greater than", "lower than", "is" and "between" or defined as single linguistic terms as it is described in [7] and [8].

Table 1. Importance degree of linguistic terms

\begin{tabular}{ll}
\hline Importance Degree & \multicolumn{1}{c}{ Linguistic Term } \\
\hline 0 & Not important (ni) \\
1 & Very lowly important (vli) \\
2 & Lowly important (li) \\
3 & Moderately important (mi) \\
4 & Highly important (hi) \\
5 & Very highly important (vhi) \\
6 & Absolutely important (ai) \\
\hline
\end{tabular}

Step 3: Collect users' opinions for criteria and alternatives: User preferences for evaluation criteria with respect to goal were given in Table 2 and alternative evaluation matrices according to evaluation criteria were given in Table $3-7$, respectively. 
Table 2. User preferences on evaluation criteria with respect to goal

\begin{tabular}{|c|c|c|c|c|c|c|}
\hline User & & $\mathrm{C} 1$ & $\mathrm{C} 2$ & C3 & $\mathrm{C} 4$ & $\mathrm{C} 5$ \\
\hline \multirow[t]{5}{*}{1} & $\mathrm{C} 1$ & - & $\begin{array}{l}\text { between li } \\
\text { and mi }\end{array}$ & $\begin{array}{l}\text { between vli } \\
\text { and mi }\end{array}$ & li & ni \\
\hline & $\mathrm{C} 2$ & $\begin{array}{l}\text { between mi } \\
\text { and hi }\end{array}$ & - & at least mi & $\mathrm{mi}$ & at most li \\
\hline & C3 & $\begin{array}{l}\text { between mi } \\
\text { and vhi }\end{array}$ & at most mi & - & $\begin{array}{l}\text { between mi } \\
\text { and hi }\end{array}$ & ni \\
\hline & $\mathrm{C} 4$ & hi & $\mathrm{mi}$ & $\begin{array}{l}\text { between li } \\
\text { and mi }\end{array}$ & - & li \\
\hline & $\mathrm{C} 5$ & ai & at least hi & ai & hi & - \\
\hline \multirow[t]{5}{*}{2} & $\mathrm{C} 1$ & - & $\begin{array}{c}\text { between li } \\
\text { and mi }\end{array}$ & $\mathrm{mi}$ & $\begin{array}{c}\text { between li } \\
\text { and mi }\end{array}$ & at most vli \\
\hline & $\mathrm{C} 2$ & $\begin{array}{l}\text { between mi } \\
\text { and hi }\end{array}$ & - & $\begin{array}{l}\text { between } \mathrm{m} \\
\text { and } \mathrm{h}\end{array}$ & $\mathrm{m}$ & at most vli \\
\hline & C3 & $\mathrm{mi}$ & $\begin{array}{l}\text { between li } \\
\text { and mi }\end{array}$ & - & at most li & at most vli \\
\hline & $\mathrm{C} 4$ & $\begin{array}{l}\text { between mi } \\
\text { and hi }\end{array}$ & $\mathrm{mi}$ & at least hi & - & $\begin{array}{c}\text { between li } \\
\text { and mi }\end{array}$ \\
\hline & $\mathrm{C} 5$ & at least vhi & at least vhi & at least vhi & $\begin{array}{l}\text { between mi } \\
\text { and hi }\end{array}$ & - \\
\hline \multirow[t]{5}{*}{3} & $\mathrm{C} 1$ & - & li & $\begin{array}{c}\text { between } \mathrm{h} \text { and } \\
\text { vh }\end{array}$ & li & at most li \\
\hline & $\mathrm{C} 2$ & hi & - & $\mathrm{h}$ & li & at most li \\
\hline & C3 & $\begin{array}{l}\text { between vli } \\
\text { and li }\end{array}$ & li & - & $\begin{array}{l}\text { between li } \\
\text { and mi }\end{array}$ & li \\
\hline & $\mathrm{C} 4$ & hi & hi & $\begin{array}{c}\text { between mi } \\
\text { and hi }\end{array}$ & - & $\begin{array}{c}\text { between vli } \\
\text { and li }\end{array}$ \\
\hline & $\mathrm{C} 5$ & at least hi & at least hi & hi & $\begin{array}{c}\text { between hi } \\
\text { and vhi }\end{array}$ & - \\
\hline
\end{tabular}

Table 3. User preferences on stroller alternatives with respect to $\mathrm{C} 1$

\begin{tabular}{|c|c|c|c|c|c|}
\hline User & & A1 & A2 & A3 & A4 \\
\hline \multirow[t]{4}{*}{1} & A1 & - & li & ni & li \\
\hline & $\mathrm{A} 2$ & hi & - & ni & li \\
\hline & A3 & ai & ai & - & between mi and hi \\
\hline & A4 & hi & hi & between li and mi & - \\
\hline \multirow[t]{4}{*}{2} & A1 & - & $\mathrm{mi}$ & at most vli & between li and mi \\
\hline & $\mathrm{A} 2$ & $\mathrm{mi}$ & - & at most li & $\mathrm{mi}$ \\
\hline & A3 & at least vhi & at least hi & - & vhi \\
\hline & A4 & between $\mathrm{mi}$ and hi & $\mathrm{mi}$ & vli & - \\
\hline \multirow[t]{4}{*}{3} & A1 & - & vli & ni & li \\
\hline & $\mathrm{A} 2$ & vhi & - & between vli and mi & between li and $\mathrm{mi}$ \\
\hline & A3 & ai & & - & hi \\
\hline & A4 & hi & between mi and hi & li & - \\
\hline
\end{tabular}


Table 4. User preferences on stroller alternatives with respect to $\mathrm{C} 2$

\begin{tabular}{|c|c|c|c|c|c|}
\hline User & & A1 & $\mathrm{A} 2$ & A3 & A4 \\
\hline \multirow[t]{4}{*}{1} & A1 & - & $\mathrm{mi}$ & between $\mathrm{mi}$ and hi & hi \\
\hline & $\mathrm{A} 2$ & $\mathrm{mi}$ & - & at least mi & $\mathrm{mi}$ \\
\hline & A3 & between li and mi & at most mi & - & at least hi \\
\hline & A4 & $\mathrm{li}$ & $\mathrm{mi}$ & at most li & - \\
\hline \multirow[t]{4}{*}{2} & A1 & - & between $\mathrm{mi}$ and hi & hi & $\mathrm{mi}$ \\
\hline & $\mathrm{A} 2$ & between li and mi & - & hi & $\mathrm{mi}$ \\
\hline & A3 & li & li & - & $\mathrm{mi}$ \\
\hline & A4 & $\mathrm{mi}$ & $\mathrm{mi}$ & $\mathrm{mi}$ & - \\
\hline \multirow[t]{4}{*}{3} & A1 & - & between mi and hi & hi & between $\mathrm{mi}$ and $\mathrm{h}$ \\
\hline & $\mathrm{A} 2$ & between li and mi & - & at least hi & at least hi \\
\hline & A3 & li & at most li & - & between vli and li \\
\hline & A4 & between li and mi & at most li & between hi and vhi & - \\
\hline
\end{tabular}

Table 5. User preferences on stroller alternatives with respect to C3

\begin{tabular}{|c|c|c|c|c|c|}
\hline User & & A1 & $\mathrm{A} 2$ & A3 & A4 \\
\hline \multirow[t]{4}{*}{1} & A1 & - & between li and mi & vli & between li and mi \\
\hline & $\mathrm{A} 2$ & between mi and hi & - & between li and mi & between $\mathrm{li}$ and $\mathrm{mi}$ \\
\hline & A3 & vhi & between mi and hi & - & at least hi \\
\hline & A4 & between mi and hi & between mi and hi & at most li & - \\
\hline \multirow[t]{4}{*}{2} & A1 & - & $\mathrm{mi}$ & between vli and mi & $\mathrm{mi}$ \\
\hline & $\mathrm{A} 2$ & $\mathrm{mi}$ & - & li & $\mathrm{mi}$ \\
\hline & A3 & between mi and vhi & hi & - & hi \\
\hline & A4 & $\mathrm{mi}$ & $\mathrm{mi}$ & li & - \\
\hline \multirow[t]{4}{*}{3} & A1 & - & between mi and hi & vli & at most li \\
\hline & $\mathrm{A} 2$ & between li and mi & - & vli & between $\mathrm{mi}$ and hi \\
\hline & A3 & vhi & vhi & - & ai \\
\hline & A4 & at least hi & between li and mi & ni & - \\
\hline
\end{tabular}

Table 6.User preferences on stroller alternatives with respect to C4

\begin{tabular}{|c|c|c|c|c|c|}
\hline User & & A1 & $\mathrm{A} 2$ & A3 & A4 \\
\hline \multirow[t]{4}{*}{1} & A1 & - & li & vli & between li and mi \\
\hline & $\mathrm{A} 2$ & hi & - & $\mathrm{li}$ & $\mathrm{mi}$ \\
\hline & A3 & vhi & hi & - & at least hi \\
\hline & A4 & between $\mathrm{mi}$ and hi & $\mathrm{mi}$ & at most li & - \\
\hline \multirow[t]{4}{*}{2} & A1 & - & vli & at most vli & li \\
\hline & $\mathrm{A} 2$ & vhi & - & at most li & $\mathrm{mi}$ \\
\hline & A3 & at least vhi & at least hi & - & vhi \\
\hline & A4 & hi & $\mathrm{mi}$ & vli & - \\
\hline \multirow[t]{4}{*}{3} & A1 & - & li & ni & between li and mi \\
\hline & $\mathrm{A} 2$ & hi & - & vli & $\mathrm{mi}$ \\
\hline & A3 & ai & between mi and hi & - & at least hi \\
\hline & A4 & between mi and hi & $\mathrm{mi}$ & at most li & - \\
\hline
\end{tabular}


Table 7. User preferences on stroller alternatives with respect to C5

\begin{tabular}{|c|c|c|c|c|c|}
\hline User & & A1 & $\mathrm{A} 2$ & A3 & A4 \\
\hline \multirow[t]{4}{*}{1} & A1 & - & at least hi & ai & between mi and hi \\
\hline & $\mathrm{A} 2$ & at most li & - & at least hi & $\mathrm{mi}$ \\
\hline & A3 & ni & at most li & - & between li and mi \\
\hline & A4 & between li and mi & $\mathrm{mi}$ & between mi and hi & - \\
\hline \multirow[t]{4}{*}{2} & A1 & - & at least mi & at least hi & between mi and vhi \\
\hline & $\mathrm{A} 2$ & at most mi & - & at least hi & $\mathrm{mi}$ \\
\hline & A3 & at most li & at most li & - & at most li \\
\hline & A4 & between vli and mi & $\mathrm{mi}$ & at least hi & - \\
\hline \multirow[t]{4}{*}{3} & A1 & - & between mi and hi & hi & between hi and vhi \\
\hline & $\mathrm{A} 2$ & between li and mi & - & ai & at least mi \\
\hline & A3 & $\mathrm{li}$ & ni & - & between vli and li \\
\hline & A4 & between vli and li & at most mi & between hi and vhi & - \\
\hline
\end{tabular}

Step 4: Transform users' opinions into HFLTS: Applying grammar rules, experts' preferences are transformed into HFLTSs. A HFLTS is represented by the terms with lowest and highest importance linguistic evaluation of user. An example of this transformation was given for the HFLTS equivalents of user preferences on criteria in Table 8.

Table 8. HFLTS equivalents of criteria evaluation

\begin{tabular}{|c|c|c|c|c|c|c|}
\hline User & & $\mathrm{C} 1$ & $\mathrm{C} 2$ & $\mathrm{C} 3$ & $\mathrm{C} 4$ & C5 \\
\hline \multirow[t]{5}{*}{1} & $\mathrm{C} 1$ & {$[-,-]$} & {$[\mathrm{li}, \mathrm{mi}]$} & [vli, mi] & {$[\mathrm{li}, \mathrm{li}]$} & [ni, ni] \\
\hline & $\mathrm{C} 2$ & {$[\mathrm{mi}, \mathrm{hi}]$} & {$[-,-]$} & [mi, ai] & {$[\mathrm{mi}, \mathrm{mi}]$} & [ni, li] \\
\hline & $\mathrm{C} 3$ & [mi, vhi] & {$[\mathrm{ni}, \mathrm{mi}]$} & {$[-,-]$} & {$[\mathrm{mi}, \mathrm{hi}]$} & {$[\mathrm{ni}, \mathrm{ni}]$} \\
\hline & $\mathrm{C} 4$ & {$[\mathrm{hi}, \mathrm{hi}]$} & {$[\mathrm{mi}, \mathrm{mi}]$} & {$[\mathrm{li}, \mathrm{mi}]$} & {$[-,-]$} & {$[\mathrm{li}, \mathrm{li}]$} \\
\hline & $\mathrm{C} 5$ & [ai, ai] & {$[\mathrm{hi}, \mathrm{ai}]$} & {$[\mathrm{ai}, \mathrm{ai}]$} & {$[\mathrm{hi}, \mathrm{hi}]$} & {$[-,-]$} \\
\hline \multirow[t]{5}{*}{2} & $\mathrm{C} 1$ & {$[-,-]$} & {$[\mathrm{li}, \mathrm{mi}]$} & {$[\mathrm{mi}, \mathrm{mi}]$} & {$[\mathrm{li}, \mathrm{mi}]$} & {$[\mathrm{ni}, \mathrm{vli}]$} \\
\hline & $\mathrm{C} 2$ & {$[\mathrm{mi}, \mathrm{hi}]$} & {$[-,-]$} & {$[\mathrm{mi}, \mathrm{hi}]$} & {$[\mathrm{mi}, \mathrm{mi}]$} & {$[\mathrm{ni}, \mathrm{vli}]$} \\
\hline & $\mathrm{C} 3$ & {$[\mathrm{mi}, \mathrm{mi}]$} & {$[\mathrm{li}, \mathrm{mi}]$} & {$[-,-]$} & {$[\mathrm{ni}, \mathrm{li}]$} & [ni, vli] \\
\hline & $\mathrm{C} 4$ & {$[\mathrm{mi}, \mathrm{hi}]$} & {$[\mathrm{mi}, \mathrm{mi}]$} & {$[\mathrm{hi}, \mathrm{ai}]$} & {$[-,-]$} & {$[\mathrm{li}, \mathrm{mi}]$} \\
\hline & $\mathrm{C} 5$ & [vhi, ai] & [vhi, ai] & [vhi, ai] & {$[\mathrm{mi}, \mathrm{hi}]$} & {$[-,-]$} \\
\hline \multirow[t]{5}{*}{3} & $\mathrm{C} 1$ & {$[-,-]$} & {$[\mathrm{li}, \mathrm{li}]$} & {$[\mathrm{hi}$, vhi] } & {$[\mathrm{li}, \mathrm{li}]$} & {$[\mathrm{ni}, \mathrm{li}]$} \\
\hline & $\mathrm{C} 2$ & {$[\mathrm{hi}, \mathrm{hi}]$} & {$[-,-]$} & {$[\mathrm{hi}, \mathrm{hi}]$} & {$[\mathrm{li}, \mathrm{li}]$} & {$[\mathrm{ni}, \mathrm{li}]$} \\
\hline & $\mathrm{C} 3$ & {$[\mathrm{vli}, \mathrm{li}]$} & {$[\mathrm{li}, \mathrm{li}]$} & {$[-,-]$} & {$[\mathrm{li}, \mathrm{mi}]$} & {$[\mathrm{li}, \mathrm{li}]$} \\
\hline & $\mathrm{C} 4$ & {$[\mathrm{hi}, \mathrm{hi}]$} & {$[\mathrm{hi}, \mathrm{hi}]$} & {$[\mathrm{mi}, \mathrm{hi}]$} & {$[-,-]$} & [vli, li] \\
\hline & C5 & {$[\mathrm{hi}, \mathrm{ai}]$} & {$[\mathrm{hi}, \mathrm{ai}]$} & [hi, hi] & [hi, vhi] & {$[-,-]$} \\
\hline
\end{tabular}

Step 5: Obtain the collective preferences: Optimistic and pessimistic corporate preferences are obtained by collecting of users' opinions via weighted sum operator. Weights of users are determined $0.5,0.3$ and 0.2 , respectively. Numerical values for optimistic and pessimistic collective preferences for criteria are given in Table 9. 
Table 9. Collective preferences for criteria

\begin{tabular}{cccccccccccc}
\hline & \multicolumn{4}{c}{ Optimistic Preferences } & \multicolumn{5}{c}{ Pessimistic Preferences } \\
\hline & C1 & C2 & C3 & C4 & C5 & C1 & C2 & C3 & C4 & C5 \\
\hline C1 & - & 2.80 & 3.40 & 2.30 & 0.70 & - & 3.70 & 4.60 & 3.70 & 0.30 \\
\hline C2 & 4.00 & - & 5.00 & 2.80 & 1.70 & 5.60 & - & 5.60 & 5.20 & 0.30 \\
\hline C3 & 3.80 & 2.80 & - & 3.20 & 0.70 & 5.00 & 2.70 & - & 2.20 & 0.70 \\
\hline C4 & 4.00 & 3.20 & 4.10 & - & 2.30 & 6.10 & 5.60 & 5.90 & - & 3.50 \\
\hline C5 & 6.00 & 6.00 & 5.60 & 4.20 & - & 9.10 & 8.10 & 9.10 & 6.10 & - \\
\hline
\end{tabular}

Step 6: Build the vector of intervals: Arithmetic mean operator used for calculation of vector of intervals. In pessimistic and optimistic corporate preference matrices, arithmetic mean of each row gives the corresponding lower and upper bound value for elements of vector of intervals.

Step 7: Obtain the priority values: Midpoints of intervals were calculated, then they are normalized. Obtained normalized values show the priority values. Computations in Step 6 and Step 7 for priority values (weights) of criteria in Table 10.

Table 10. Calculation of priority values

\begin{tabular}{|c|c|c|c|c|}
\hline & \multicolumn{2}{|c|}{ Interval Utilities } & Midpoints & Weights \\
\hline $\mathrm{C} 1$ & 3.075 & 2.300 & 2.688 & 0.133 \\
\hline $\mathrm{C} 2$ & 4.175 & 3.375 & 3.775 & 0.187 \\
\hline $\mathrm{C} 3$ & 2.650 & 2.625 & 2.638 & 0.130 \\
\hline $\mathrm{C} 4$ & 5.275 & 3.400 & 4.338 & 0.215 \\
\hline $\mathrm{C} 5$ & 8.100 & 5.450 & 6.775 & 0.335 \\
\hline
\end{tabular}

Step 8: Selection of the best stroller: The best stroller was determined by multiplication of alternative priorities in views of each criteria and criteria weights. Priority values of alternatives can also be calculated by following application steps. Priority values of alternatives were calculated and given here and the final evaluation scores of alternatives calculated as given in Eq. (1) as follows:

$$
\left[\begin{array}{lllll}
0.135 & 0.291 & 0.189 & 0.126 & 0.379 \\
0.195 & 0.284 & 0.227 & 0.244 & 0.276 \\
0.419 & 0.208 & 0.359 & 0.409 & 0.082 \\
0.251 & 0.218 & 0.224 & 0.221 & 0.263
\end{array}\right] \times\left[\begin{array}{l}
0.133 \\
0.187 \\
0.130 \\
0.215 \\
0.335
\end{array}\right]=\left[\begin{array}{l}
0.2509 \\
0.2535 \\
0.2566 \\
0.2389
\end{array}\right]
$$

The alternative with the highest score in the equation above is the best stroller. So, the parents should buy A3. A2 follows A3 with a small difference. A1 and A4 is the priority order of other alternatives.

\section{Summary and Conclusions}

Fuzzy MCDM applications have an extensive application area in the literature. Since these approaches helps modelling linguistic and uncertain feelings of decision makers, they are very useful to cope with uncertainty faced in decision problems.

Parent candidate are generally excited about having a new baby. They are also feel hesitant about the things required for the baby, because there too many alternatives for each item in their shopping list. Alternatives for each item have different advantages over another one. So, making a clear expression about their opinions is commonly hard.

HFLTS approach makes it possible for decision makers to indicate their feelings by using different linguistic terms. By the way, uncertainty and hesitant feelings can be defined in decision models.

In this study, HFLTS based GDM was used for determination of the best stroller for a family, who will have a new baby. Opinions of three users defined by hesitant fuzzy linguistic statements were 
aggregated by weighted sum operator and four alternatives were determined by considering five evaluation criteria. A3 is determined as the best stroller.

Applications of decision making are not very similar for this kind of decisions. So, this study can be extended with proposing an optimization model that contains selection of different items needed for a baby under a budget limitation. A very promising extension way to this study can be made by consideration of different criteria in the evaluation process. Hybrid decision making methods, which integrate different approaches such as TOPSIS, VIKOR, ELECTRE, etc. can be utilized to obtain solution to the problem. Different fuzzy sets i.e. intuitionistic, neutrosophic, type-II, etc. can also be taken into consideration.

\section{Statement of Research and Publication Ethics}

The authors declare that this study complies with Research and Publication Ethics.

\section{References}

[1] Zadeh L.A. 1965. Fuzzy sets. Information and Control, 8: 338-353.

[2] Bellman R.E., Zadeh L.A. 1970. Decision-making in a fuzzy environment. Management Science Series B-Application, 17: B141-B164.

[3] Zadeh L.A. 1975. Concept of a linguistic variable and its application to approximate reasoning1. Information Sciences, 8: 199-249.

[4] Atanassov K.T. 1986. Intuitionistic fuzzy-sets. Fuzzy Sets and Systems, 20: 87-96.

[5] Smaradache F. 2002. A unifying field in logics: Neutrosophic logic. Multiple-Valued Logic, 8: 385-438.

[6] Torra V. 2010. Hesitant fuzzy sets. International Journal of Intelligent Systems, 25: 529-539.

[7] Rodriguez R.M., Martinez L. Herrera F. 2012. Hesitant fuzzy linguistic term sets for decision making. IEEE Transactions on Fuzzy Systems, 20: 109-119.

[8] Yavuz M., Oztaysi B., Onar, S.C., Kahraman C. 2015. Multi-criteria evaluation of alternative fuel vehicles via a hierarchical hesitant fuzzy linguistic model. Expert Systems with Applications, 42: 2835-2848.

[9] Wang J., Wang J.Q., Zhang H.Y. 2016. A likelihood-based TODIM approach based on multi hesitant fuzzy linguistic information for evaluation in logistics outsourcing. Computers \& Industrial Engineering, 99: 287-299.

[10] Sun, R.X., Hu J.H., Zhou J.D., Chen X.H. 2018. A hesitant fuzzy linguistic projection based mabac method for patients' prioritization. International Journal of Fuzzy Systems, 20: 2144-2160.

[11] Wu Z.B., Xu J.P., Jiang X.L., Zhong L. 2019. Two MAGDM models based on hesitant fuzzy linguistic term sets with possibility distributions: VIKOR and TOPSIS. Information Sciences, 473: 101-120.

[12] Ji P., Zhang H.Y., Wang J.Q. 2018. A projection-based outranking method with multi hesitant fuzzy linguistic term sets for hotel location selection. Cognitive Computation, 10: 737-751.

[13] Liao H.C., Wu X.L., Liang X.D., Xu J.P., Herrera F. 2018. A new hesitant fuzzy linguistic ORESTE method for hybrid multicriteria decision making. IEEE Transactions on Fuzzy Systems, 26: 3793-3807.

[14] Xue Y.X., You J.X., Zhao X.F., Liu H.C. 2016. An integrated linguistic MCDM approach for robot evaluation and selection with incomplete weight information. International Journal of Production Research, 54: 5452-5467.

[15] Wu Y.N., Wang Y., Chen K. F., Xu C. B., Li L.W.Y. 2017. Social sustainability assessment of small hydropower with hesitant PROMETHEE method. Sustainable Cities and Society, 35: 522537.

[16] Wu Y.N., Zhou, J.L. 2019. Risk assessment of urban rooftop distributed PV in energy performance contracting (EPC) projects: An extended HFLTS-DEMATEL fuzzy synthetic evaluation analysis. Sustainable Cities and Society, 47: 101524.

[17] Liao H.C., Mi, X.M., Yu Q., Luo L. 2019. Hospital performance evaluation by a hesitant fuzzy linguistic best worst method with inconsistency repairing. Journal of Cleaner Production, 232: 657-671. 
[18] Ozkan B., Ozceylan E., Kabak M. Dagdeviren M. 2020. Evaluating the websites of academic departments through SEO criteria: a hesitant fuzzy linguistic MCDM approach. Artificial Intelligence Review, 53: 875-905.

[19] Boyaci A.C. 2020. Selection of eco-friendly cities in Turkey via a hybrid hesitant fuzzy decision making approach. Applied Soft Computing, 89: 106090.

[20] Hai W., Xu Z.S., Zeng X.J. 2018. Hesitant fuzzy linguistic term sets for linguistic decision making: Current developments, issues and challenges. Information Fusion, 43: 1-12.

[21] Liao H.C., Xu Z.S., Herrera-Viedma E., Herrera F. 2018. Hesitant fuzzy linguistic term set and its application in decision making: A state-of-the-art survey. International Journal of Fuzzy Systems, 20: 2084-2110. 